\title{
Resusitasi Cairan: dari Dasar Fisiologis hingga Aplikasi Klinis
}

Antonius H. Pudjiadi

Departemen Ilmu Kesehatan Anak Fakultas Kedokteran Universitas Indonesia/RS Dr. Cipto Mangunkusumo, Jakarta

\begin{abstract}
Abstrak
Resusitasi cairan merupakan langkah penting tata laksana syok pada anak. Kebutuhan resusitasi cairan sangat individual. Pemberian cairan yang tidak tepat dapat membahayakan keadaan pasien. Tinjauan pustaka ini akan membahas fisiologi dasar sistem hemodinamik, khususnya dalam kaitannya dengan resusitasi cairan. Berbagai protokol pemberian resusitasi cairan akan dibahas secara teknik, serta masalahnya pada penggunaannya dalam klinis. Sari Pediatri 2017;18(5):409-16
\end{abstract}

Kata kunci: tata laksana syok, sistem hemodinamik, resusitasi cairan

\section{Fluid Resuscitation: From Bench to Bedside}

Antonius H. Pudjiadi

\begin{abstract}
Fluid resucitation is a corner stone in the management of shock in children. However the benefit of fluid resuscitation depends on other hemodynamic conditions. Failure to identify haemodynamic status may compromise patient condition. This review will discuss the basic physiology of haemodynamic system related to fluid resucitation. Recent fluid resuscitation strategy will be explained in detail from the basics to bedside. Sari Pediatri 2017;18(5):409-16
\end{abstract}

Keyword: management of shock, haemodynamic status, fluid resuscitation

Alamat korespondensi: Dr. Antonius H. Pudjiadi, SpA(K). Departemen Ilmu Kesehatan Anak Fakultas Kedokteran Universitas Indonesia/RS Dr. Cipto Mangunkusumo, Jakarta. Jln. Diponegoro no.71, Jakarta. E-mail: ahpudjiadi@gmail.com 
$\mathrm{P}$ engetahuan tentang fisiologi ventrikel sangat berkembang sejak Frank, ${ }^{1}$ seorang peneliti Jerman, melakukan penelitian pada sediaan jantung kodok, pada tahun 1894. Hasil penelitian ini diperkuat oleh Patterson dan Starling ${ }^{2}$ yang melakukan penelitian pada sediaan jantung anjing, pada tahun 1914. Mereka mendapatkan bahwa kontraksi sistolik ventrikel berkorelasi secara proporsional dengan regangan pada fase diastolik. Pada tahun 1970, Swan dan rekan memperkenalkan kateter arteri pulmonalis. ${ }^{3}$ Penggunaan kateter arteri pulmonalis memungkinkan pengukuran curah jantung sehingga pasokan oksigen dapat dihitung. Selanjutnya konsep syok berubah, dari sindrom klinis menjadi keseimbangan antara konsumsi dan pasokan oksigen. Curah jantung menjadi target utama terapi dengan pemberian cairan resusitasi untuk meningkatan preload. ${ }^{4-6}$ Akhir-akhir ini, beberapa penelitian menunjukkan bahwa pemberian cairan resusitasi dapat meningkatkan morbiditas dan mortalitas anak. ${ }^{7}$

${ }^{8}$ Pembahasan berikut akan mengupas aplikasi hukum
Frank-Starling dalam tatalaksana syok, sesuai konsep yang berkembang saat ini.

\section{Hemodinamik praktis}

Target resusitasi adalah meningkatkan pasokan oksigen $\left(\mathrm{DO}_{2}\right)$ agar dapat memenuhi kebutuhan konsumsi oksigen $\left(\mathrm{VO}_{2}\right)$. Pasokan oksigen merupakan fungsi curah jantung dikali kandungan oksigen darah arteri. Kandungan oksigen darah arteri terdiri dari oksigen yang terikat hemoglobin dan oksigen yang terlarut. Kandungan oksigen vena sentral adalah oksigen yang terikat hemoglobin ditambah oksigen terlarut yang terukur di vena sentral. Konsumsi oksigen adalah curah jantung dikali selisih kandungan oksigen antara arteri dan vena (Tabel 1).

Secara klinis, kinerja jantung diperankan oleh curah jantung. Untuk memantau kinerja jantung, seringkali digunakan nilai indeks (cardiac index=CI), yaitu cardiac output dibagi luas permukaan tubuh. Curah jantung

Tabel 1. Beberapa persamaan hemodinamik

\begin{tabular}{lcc}
\hline Parameter & Formula \\
\hline Kandungan oksigen darah arteri & $\left(\mathrm{CaO}_{2}\right)$ & $\mathrm{Hbx} 1,34 \times \mathrm{xaO}_{2}+0,0031 \mathrm{xPaO}_{2}$ \\
Kandungan oksigen darah vena sentral & $\left(\mathrm{CcvO}_{2}\right)$ & $\mathrm{Hbx} 1,34 \mathrm{xSvO}_{2}+0,0031 \mathrm{xPvO}_{2}$ \\
Pasokan oksigen tubuh & $\left(\mathrm{DO}_{2}\right)$ & $\mathrm{COxCaO}_{2}$ \\
Konsumsi oksigen tubuh & $\left(\mathrm{VO}_{2}\right)$ & $\mathrm{COx}\left(\mathrm{CaO}_{2}-\mathrm{CvO}_{2}\right)$ \\
Oxygen extraction ratio & $(\mathrm{OER})$ & $\left(\mathrm{SaO}_{2}-\mathrm{ScvO}_{2}\right) / \mathrm{SaO}_{2}$ \\
Systemic vascular resistance & $(\mathrm{SVR})$ & $80 \mathrm{x}(\mathrm{MAP}-\mathrm{CVP}) / \mathrm{CO}$ \\
\hline Unt
\end{tabular}

Unit pengukuran: kadar hemoglobin $(\mathrm{Hb})$ dalam g/L; $\mathrm{CaO}_{2}$ dan $\mathrm{CvO}_{2}$ dalam $\mathrm{mL} \mathrm{O}_{2} / \mathrm{L} ; \mathrm{DO}_{2}$ dan $\mathrm{VO}_{2}$ dalam $\mathrm{mL} \mathrm{O}_{2}$ /menit; OER dalam fraksi 1; MAP dan CVP dalam mm Hg; CO dalam L/menit; SVR dalam dyn.s.cm ${ }^{5}$

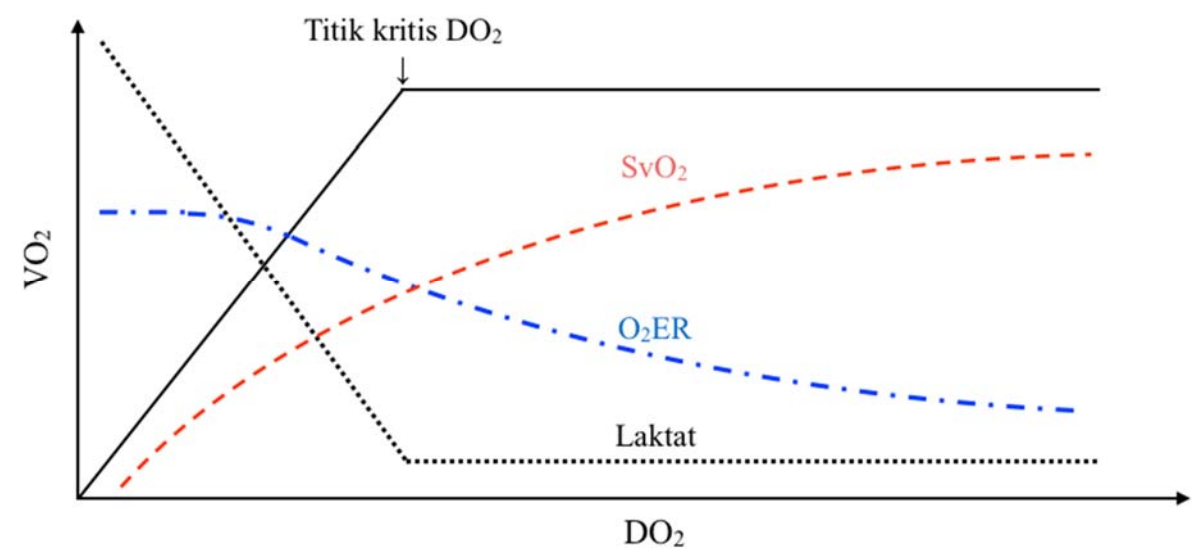

Gambar 1. Hubungan antara $\mathrm{DO}_{2}, \mathrm{VO}_{2}, \mathrm{O}_{2} \mathrm{ER}, \mathrm{ScvO}_{2}$ dan Laktat 
(cardiac output $=\mathrm{CO}$ ) dipengaruhi oleh isi sekuncup (stroke volume $=S V$ ) dan frekuensi denyut jantung. Isi sekuncup dipengaruhi preload, afterload dan kontraktilitas. Apabila curah jantung dapat diukur, afterload dapat dihitung dengan memasukan nilai tekanan darah sistemik dan tekanan vena sentral, dinyatakan sebagai systemic vascular resistance (SVR) (Tabel 1). Banyak parameter pengukuran yang digunakan sebagai indikator preload dan kontraktilitas, tetapi karena sifatnya yang dinamis dan individual, penilaian secara matematis umumnya sulit digunakan secara umum dalam klinis. Sejak satu abad terakhir ini untuk mengoptimalkan preload dan kotraktilitas digunakan prinsip dasar yang mengacu pada hukum Frank-Starling.

Ketika isi sekuncup menurun secara akut, tubuh mengadakan kompensasi melalui sistem endokrin dan saraf otonom sehingga denyut jantung dan SVR meningkat. Kondisi ini akan mempertahankan curah jantung dan perfusi organ vital. Apabila pasokan masih tidak mencukupi maka akan terjadi peningkatan oxygen extraction ratio $\left(\mathrm{O}_{2} \mathrm{ER}\right)$, sehingga saturasi vena sentral akan menurun. Pada keadaan lanjut, bila kebutuhan oksigen tetap tidak terpenuhi, akan terjadi metabolisme anaerob yang, antara lain, dapat dinilai dengan peningkatan kadar laktat darah (Gambar 1).

\section{Klasifikasi syok}

Syok dapat terjadi karena kekurangan volume intravaskular (syok hipovolemik), kegagalan jantung (syok kardiogenik) dan karena gangguan tonus sistem vaskular (syok distributif). Penyebab utama syok hipovolemik pada anak, antara lain, adalah akibat gastroenteritis dan perdarahan. Penyebab utama syok kardiogenik adalah miokardiopati atau miokarditis. Penyebab utama syok distributif adalah anafilaksis, sepsis atau syok neurogenik akibat gangguan saraf otonom. Klasifikasi lain memasukkan juga syok jenis lain seperti syok obstruktif. ${ }^{9}$ Syok obstruktif terjadi akibat faktor di luar sistem kardiovaskular yang memengaruhi curah jantung, misalnya akibat pneumotoraks, tamponade dan emboli paru. Di University Medical Center, University of Nevada, antara tahun 1998-2006, terdapat 147 kasus syok pada anak di ruang gawat darurat; $81 \%$ kasus syok hipovolemik, $14 \%$ distributif, dan 5\% kardiogenik. ${ }^{10}$ Ferrari dan rekan memperlihatkan parameter hemodinamik pada beberapa jenis syok (Tabel 2). Data di Rumah Sakit Dr Cipto Mangunkusumo pada satu jam pasca resusitasi, terdapat $66 \%$ anak dengan cardiac index (CI) normal, $20 \%$ CI tinggi dan $14 \%$ CI rendah. ${ }^{11}$ Di antara anak dengan CI normal terdapat 58\% tidak responsif lagi terhadap cairan. Empat puluh persen anak dengan CI tinggi tidak responsif lagi terhadap cairan, dan $86 \%$ anak dengan CI rendah tidak responsif lagi terhadap cairan.

\section{Hukum Frank Starling}

Hukum Frank-Starling pada dasarnya menerangkan sifat intrinsik miokardium. Peningkatan panjang otot jantung (pada pengisian ventrikel) berkorelasi positif dengan peningkatan tekanan ventrikel. Pada tingkat molekular, peningkatan end-diastolic volume berkorelasi dengan peningkatan cross-bridges antar filamen tipis. ${ }^{13}$ Secara klinis, karakteristik intrinstik miokardium ini diaplikasikan dengan meningkatkan preload untuk meningkatkan isi sekuncup.

Tabel 2. Parameter hemodinamik makro pada berbagai tipe syok

\begin{tabular}{llccc}
\hline Tipe syok & Patofisiologi & CO & SVR & PCWP \\
\hline Hipovolemik & Kehilangan cairan intravaskular, vasokonstriksi & $=$ & $\uparrow \uparrow$ & $\downarrow \downarrow$ \\
Kardiogenik & Curah jantung berkurang, redistribusi & $\downarrow \downarrow$ & $\uparrow$ & $\uparrow \uparrow$ \\
Sepsis & Vasodilatasi patologis & $\uparrow$ & $\downarrow \downarrow$ & $\downarrow$ \\
Anafilaksis & Vasodilatasi akibat histamine & $\uparrow \uparrow$ & $\downarrow \downarrow$ & $\downarrow$ \\
Neurogenic & Vasodilatasi patologis & $\uparrow$ & $\downarrow$ & $\downarrow$ \\
\hline Dikutip dan adaptasi dari Ferrari dkk, 2011 & & \\
CO= Cardiac Output , SVR $=$ Systemic Vascular Resistance; PCWP $=$ Pulmonary Capillary Wedge Pressure (digunakan \\
sebagai parameter preload).
\end{tabular}


Pada tahun 1954, Sarnoff dan Berglund ${ }^{14}$ mengkaji hukum Frank-Starling pada sistem sirkulasi anjing secara utuh. Mereka menemukan kinerja ventrikel kiri dan isi sekuncup meningkat tajam sejalan dengan peningkatan preload, sampai tekanan tertentu menjadi mendatar. Bila arteri koroner diikat, kinerja ventrikel kiri dan isi sekuncup maksimal lebih rendah. Jika preload ditingkatkan, kinerja ventrikel kiri dan isi sekuncup akan menurun (Gambar 2).

Dari penelitian tersebut didapatkan kurva FrankStarling dibagi menjadi dua bagian. Bagian yang menggambarkan peningkatan tajam isi sekuncup pada setiap perubahan preload dikenal dengan istilah daerah preload dependence. Bagian yang menggambarkan peningkatan tidak nyata isi sekuncup pada setiap perubahan preload dikenal dengan daerah preload independence (Gambar 3).

\section{Protokol resusitasi cairan}

Rivers $\mathrm{dkk}^{5}$ mengajukan metode early goal directed therapy sebagai cara mengatasi syok septik (pada orang dewasa). Langkah awal protokol tersebut adalah pemberian bolus kristaloid sebanyak $500 \mathrm{ml}$ tiap 30 menit untuk mencapai tekanan vena sentral (central

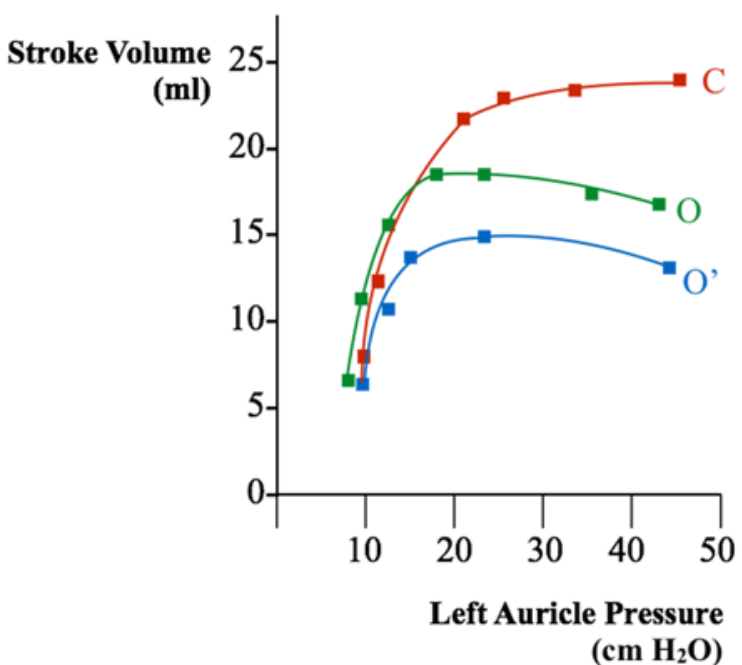

Gambar 2. Kinerja ventrikel kiri dan pengaruh penyempitan arteri koroner utama pada kurva Frank-Starling. C=kurva tanpa restriksi; $\mathrm{O}=$ kurva dengan penyempitan arteri koroner ringan; O'=kurva dengan penyempitan arteri koroner lebih berat. Modifikasi dari Sarnoff dan Berglund, 1954. ${ }^{14}$ venous pressure $=\mathrm{CVP}$ ) $8-12 \mathrm{mmHg}$. Selanjutnya, bila mean arterial pressure kurang dari $65 \mathrm{mmHg}$, protokol menganjurkan pemberian vasopresor untuk mempertahankan tekanan minimal $65 \mathrm{mmHg}$. Jika mean arterial pressure lebih dari $90 \mathrm{mmHg}$, protokol menganjurkan pemberian vasodilator. Pemberian cairan resusitasi hingga nilai CVP tertentu, dikenal dengan metode statis. Kelemahan metode ini adalah menggunakan nilai baku yang sama untuk semua orang. Ketika kontraktilitas menurun, nilai statis yang ditentukan dapat berada pada daerah preload independence kurva Frank-Starling.

Pada tahun 1979, Weil dan Henning 9 memperkenalkan teknik fluid challenge dengan metode dinamis yang kemudian di kenal dengan rule of Weil atau perasat 5-2. Metode ini mempertimbangkan status preload pada kurva Frank Starling yang ditentukan oleh compliance jantung. Compliance adalah ukuran distensibilitas stuktur sferis yang ditetukan oleh perubahan volume untuk setiap perubahan tekanan (pressure). Berdasarkan pemikiran ini, maka peningkatan nilai CVP yang tinggi secara mendadak, menandakan penurunan compliance jantung, atau kurva Frank-Starling telah sampai pada daerah preload independence. Perasat Weil menganjurkan pemberian cairan resusitasi yang dipandu nilai CVP. Apabila CVP kurang atau sama dengan $8 \mathrm{~cm} \mathrm{H}_{2} \mathrm{O}$ maka cairan resusitasi diberikan $200 \mathrm{ml}$ melalui vena perifer, dalam waktu 10 menit (Tabel 3). Jika CVP lebih dari $8 \mathrm{~cm}$ $\mathrm{H}_{2} \mathrm{O}$, tetapi kurang dari $14 \mathrm{~cm} \mathrm{H}_{2} \mathrm{O}$ maka cairan resusitasi diberikan $100 \mathrm{ml}$ dalam waktu 10 menit. Jika

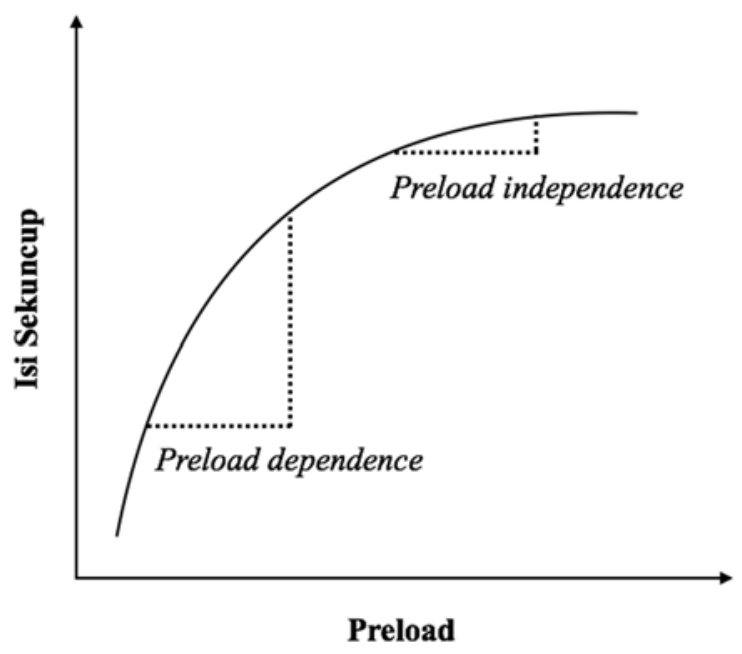

Gambar 3. Fungsi ventrikel pada kurva Frank-Starling 
Antonius H. Pudjiadi dkk: Resusitasi cairan: dari dasar fisiologis hingga aplikasi klinis

Tabel 3. Panduan pemberian cairan resusitasi

\begin{tabular}{lll}
\hline & Nilai CVP & Pemberian Cairan \\
\hline Nilai CVP & $<8 \mathrm{~cm} \mathrm{H} 2 \mathrm{O}$ & $20 \mathrm{ml} / \mathrm{kg} / 10$ menit \\
& $<14 \mathrm{~cm} \mathrm{H} 2 \mathrm{O}$ & $10 \mathrm{ml} / \mathrm{kg} / 10$ menit \\
& $>14 \mathrm{~cm} \mathrm{H} 2 \mathrm{O}$ & $5 \mathrm{ml} / \mathrm{kg} / 10$ menit \\
\hline Nilai CVP selama pemberian cairan & Meningkat $>5 \mathrm{~cm} \mathrm{H} 2 \mathrm{O}$ & Hentikan cairan \\
\hline Nilai CVP setelah pemberian cairan & Meningkat $<2 \mathrm{~cm} \mathrm{H} 2 \mathrm{O}$ & Ulangi dari awal \\
& Meningkat $>2 \mathrm{~cm} \mathrm{H} 2 \mathrm{O},<5 \mathrm{~cm} \mathrm{H} 2 \mathrm{O}$ & Pantau CVP 10 menit lagi* \\
& Meningkat $>5 \mathrm{~cm} \mathrm{H2O}$ & Hentikan cairan \\
\hline
\end{tabular}

*Bila setelah pemantauan nilai CVP tetap $>2 \mathrm{~cm} \mathrm{H} 2 \mathrm{O}$. Pemberian cairan dihentikan; bila nilai CVP turun $>2 \mathrm{~cm} \mathrm{H2O}$, pemberian cairan diulangi dari awal

Dikutip dan adaptasi dari menurut Weil dan Henning 1979 (modifikasi) $^{9}$

CVP sama atau lebih besar dari $14 \mathrm{~cm} \mathrm{H}_{2} \mathrm{O}$, cairan resusitasi diberikan $50 \mathrm{ml}$ dalam waktu 10 menit. Namun, apabila selama pemberian cairan resusitasi, nilai CVP meningkat lebih dari $5 \mathrm{~cm} \mathrm{H}_{2} \mathrm{O}$, pemberian cairan harus dihentikan. Jika setelah pemberian cairan resusitasi CVP meningkat lebih dari $5 \mathrm{~cm} \mathrm{H}_{2} \mathrm{O}$ pemberian cairan tidak dilanjutkan, sedangkan bila kurang dari $2 \mathrm{~cm} \mathrm{H}_{2} \mathrm{O}$, pemberian cairan diulangi dari langkah awal. Apabila CVP meningkat kurang dari 5 $\mathrm{cm} \mathrm{H}_{2} \mathrm{O}$ tetapi lebih dari $2 \mathrm{~cm} \mathrm{H}_{2} \mathrm{O}$ dari nilai awal, pasien dipantau selama 10 menit; tetapi jika setelah pemantauan nilai CVP tetap lebih dari $2 \mathrm{~cm} \mathrm{H}_{2} \mathrm{O}$, pemberian cairan resusitasi dihentikan. Pada keadaan CVP turun kembali hingga $2 \mathrm{~cm} \mathrm{H}_{2} \mathrm{O}$ atau lebih rendah, pemberian cairan diulangi dari awal hingga tanda syok teratasi. Penyesuaian jumlah cairan terhadap kenaikan CVP bertujuan untuk mencegah pemberian cairan berlebihan di luar kemampuan jantung.

Pada tahun 1999, Michard dkk ${ }^{15}$ melaporkan bahwa variasi tekanan arteri (pulse pressure variation=PPV), pada pasien acute lung injury (ALI) yang menggunakan ventilator, dapat digunakan untuk menduga hemodinamik pada pemberian cairan resusitasi (Gambar 4). PPV dibakukan dengan rumus 1, sebagai berikut:

$\Delta P P(\%)=100 \times \frac{(P P \max -P P \min ) /(P P \max +P P \min )}{2}$

Rumus 1. Pulse Pressure Variation. Keterangan: $\Delta \mathrm{PP}=$ pulse pressure variation dinyatakan dalam persen; PPmax=tekanan nadi tertinggi; PPmin=tekanan nadi terendah

Penilaian PPV sebagai pedoman pemberian cairan resusitasi juga tergolong metode dinamis. Perubahan PPV terjadi akibat siklus ventilasi mekanik yang memengaruhi hemodinamik di daerah preload dependence kurva Frank-Starling. Pada fase inspirasi, tekanan intratoraks meningkat. Peningkatan tekanan intratoraks akan mengakibatkan penurunan preload dan peningkatan afterload ventrikel kanan, mengakibatkan penurunan isi sekuncup ventrikel kanan. Namun demikian, tekanan positif juga akan mendorong darah yang berada dalam vaskular paru, sehingga meningkatkan preload ventrikel kiri. Tekanan positif intratoraks juga meringankan kerja ventrikel kiri yang harus mendorong darah ke luar rongga torak. Karena itu pada fase inspirasi, isi sekuncup ventrikel kiri meningkat, sedangkan pada fase ekspirasi, tekanan intratoraks menurun kembali. Pada fase ini, preload ventrikel kanan meningkat dan afterload ventrikel kanan menurun. Kondisi ini mengakibatkan peningkatan isi sekuncup ventrikel kanan. Namun demikian, penurunan isi sekuncup ventrikel kanan pada fase inspirasi akan menjadi preload ventrikel kiri pada fase ini. Demikian pula tugas ventrikel kiri memompa darah ke luar rongga torak, mendapat bantuan tekanan positif intratorak tidak sebesar seperti pada fase inspirasi. Oleh karena itu, pada fase ekspirasi, isi sekuncup ventrikel kiri menurun (Gambar 5). Telaah sistematik oleh Marik dan rekan, pada tahun 2009, memperlihatkan bahwa PPV $(12.5 \pm 1.6) \%$ mempunyai sensitivitas $89 \%$ dan spesifisitas $88 \%$ dalam menilai fluid responsiveness. ${ }^{16}$

Brierley $\mathrm{dkk}^{6}$ menganjurkan penggunaan bolus cairan isotonik atau albumin $5 \% 20 \mathrm{ml} / \mathrm{kg}$ berat badan sebagai langkah awal resusitasi pada anak. Pemberian cairan dapat diulangi dengan target tekanan darah dan perfusi yang normal. Pemberian cairan harus 

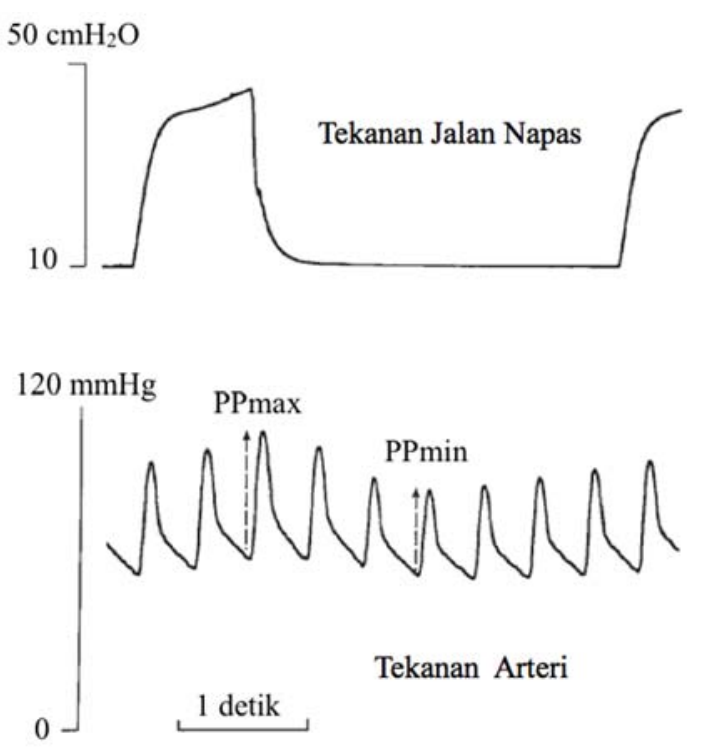

Gambar 4. Pulse Pressure Variation (PPV). Dikutip dan modifikasi dari Michard dkk, 1999. ${ }^{15}$ dihentikan bila terdapat tanda gagal jantung. Jika syok belum teratasi, langkah selanjutnya adalah penggunaan dopamin melalui akses sentral. Teknik pemberian cairan sebagai uji kemampuan jantung dikenal dengan metode simulasi. Kekuatan metode ini adalah kepastian akan kemampuan jantung terhadap peningkatan preload sehingga metode ini sering digunakan sebagai baku emas. Kelemahan metode Brierley dkk adalah penghentian cairan setelah terjadi gagal jantung.

Semakin berkembang teknik echocardiography, tata laksana syok pada anak dapat dilakukan dengan lebih mudah. Lukito $\mathrm{dkk}^{17}$ menggunakan perasat passive leg rising untuk memperkirakan respons fluid challenge pada anak usia 1-8 tahun. Teknik ini juga merupakan metode simulasi. Perasat passive leg rising, menurut Lukito dkk, diawali dengan mengukur curah jantung pada posisi kepala dan badan anak membentuk sudut $45^{\circ}$ terhadap bidang horizontal (Gambar 6). Posisi anak kemudian diubah dengan ekstremitas inferior anak membentuk sudut $45^{\circ}$ terhadap kepala dan badan yang dibuat horizontal. Apabila pada posisi ini terdapat
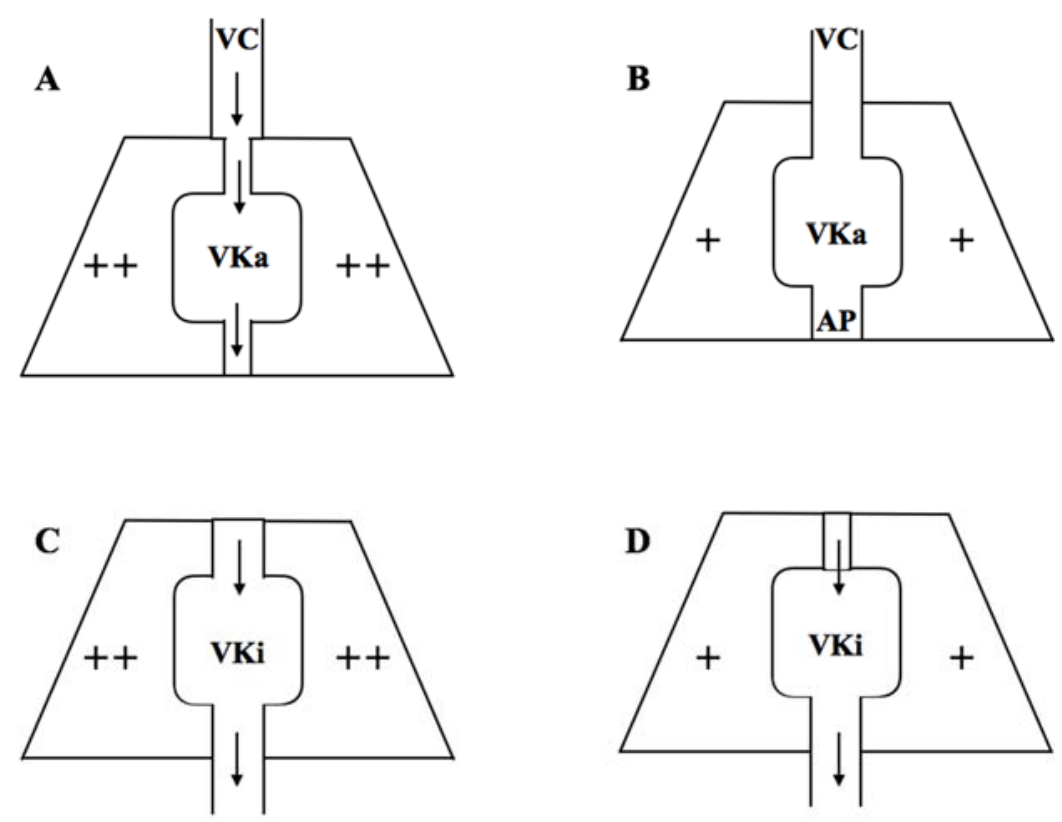

Gambar 5. Pengaruh ventilasi tekanan positif terhadap kinerja ventrikel kanan dan kiri. A. Isi sekuncup ventrikel kanan pada fase inspirasi ventilasi mekanik. B Isi sekuncup ventrikel kanan pada fase ekspirasi ventilasi mekanik. C. Isi sekuncup ventrikel kiri pada fase inspirasi ventilasi mekanik. D. Isi sekuncup ventrikel kiri pada fase ekspirasi ventilasi mekanik. Keterangan: $\mathrm{VC}=$ vena cava; $\mathrm{VKa}=$ ventrikel kanan; $\mathrm{VKi}=$ ventrikel kiri; $\mathrm{AP}=$ arteri pulmonalis. 
peningkatan curah jantung $\geq 10 \%$, yang diukur dengan teknik echocardiography, kemungkinan kurva FrankStarling berada pada daerah preload dependence dengan sensitivitas 55\% dan spesifisitas $85 \%$.

Teknik echocardiography juga memungkinkan pengukuran diameter vena cava inferior. Pada pernapasan spontan, indeks kolapsibilitas vena cava inferior berkorelasi dengan tekanan atrium kanan. ${ }^{18-20}$ Indeks kolapsibilitas adalah presentasi penurunan diameter vena cava pada fase inspirasi yang diukur dengan rumus 2 , sebagai berikut:

$$
c I V C=\frac{(I V C \max -I V C \min )}{I V C \max } x 100
$$

Rumus 2. Indeks kolapsibilitas vena cava inferior. Keterangan: cIVC=indeks kolapsibilitas vena cava inferior; IVCmax= diameter terbesar vena cava inferior yang diukur dengan teknik echocardiography; IVCmin=diameter terkecil vena cava inferior yang diukur dengan teknik echocardiography.

Indeks kolapsibilitas $>50 \%$ berkorelasi dengan tekanan atrium kanan $<10 \mathrm{mmHg} .{ }^{19}$ Ventilator tekanan positif akan memengaruhi diameter vena cava inferior, terutama bila tekanan akhir ekspirasi (positive end expiratory pressure $=\mathrm{PEEP}$ ) tinggi. Airapetian $\mathrm{dkk}^{21}$ melaporkan kolapsibilitas $>42 \%$ dapat memprediksi peningkatan curah jantung setelah pemberian cairan resusitasi dengan spesifisitas $97 \%$ dan positive predictive value (PPV) 90\%.

\section{Kesimpulan}

Resusitasi cairan merupakan bagian dari tata laksana hemodinamik yang bertujuan untuk mencukupi kebutuhan oksigen. Keberhasilan resusitasi cairan amat tergantung pada kinerja jantung. Otto Frank, Patterson dan Starling, serta Sarnoff dan Berglund telah meletakkan dasar fisiologis kinerja jantung. ${ }^{1}$

2, 14 Aplikasi klinis dari penelitian dasar tersebut sangat individual dan membutuhkan pemahaman hemodinamik yang utuh.

\section{Daftar pustaka}

1. Zimmer HG. Otto Frank and the fascination of high-tech cardiac physiology. Clin Cardiol 2004;27:665-6.

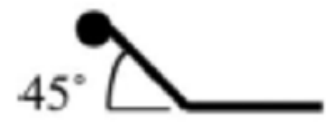

Posisi Awal

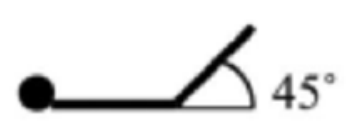

Posisi PLR
Gambar 6. Posisi anak pada perasat passive leg rising (PLR) Dikutip dan modifikasi dari Lukito dkk, 2012. ${ }^{17}$

2. Patterson SW, Starling EH. On the mechanical factors which determine the output of the ventricles. J Physiol 1914;48:35779.

3. Swan HJ, Ganz W, Forrester J, Marcus H, Diamond G, Chonette D. Catheterization of the heart in man with use of a flow-directed balloon-tipped catheter. N Engl J Med 1970;283:447-51.

4. Carcillo JA, Davis AL, Zaritsky A. Role of early fluid resuscitation in pediatric septic shock. JAMA 1991;266:1242-5.

5. Rivers E, Nguyen B, Havstad S, Ressler J, Muzzin A, Knoblich B, dkk. Early goal-directed therapy in the treatment of severe sepsis and septic shock. N Engl J Med 2001;345:1368-77.

6. Brierley J, Carcillo JA, Choong K, Cornell T, Decaen A, Deymann A, dkk. Clinical practice parameters for hemodynamic support of pediatric and neonatal septic shock: 2007 update from the American College of Critical Care Medicine. Crit Care Med 2009;37:666-88.

7. Maitland K, Kiguli S, Opoka RO, Engoru C, Olupot-Olupot P, Akech SO, dkk. Mortality after fluid bolus in African children with severe infection. N Engl J Med 2011;364:2483-95.

8. Sinitsky L, Walls D, Nadel S, Inwald DP. Fluid overload at 48 hours is associated with respiratory morbidity but not mortality in a general PICU: retrospective cohort study. Pediatr Crit Care Med 2015;16:205-9.

9. Weil MH, Henning RJ. New concepts in the diagnosis and fluid treatment of circulatory shock. Thirteenth annual Becton, Dickinson and Company Oscar Schwidetsky Memorial Lecture. Anesth Analg 1979;58:124-32.

10. Fisher JD, Nelson DG, Beyersdorf H, Satkowiak LJ. Clinical spectrum of shock in the pediatric emergency department. Pediatr Emerg Care 2010;26:622-5.

11. Yuliarto S. Perubahan parameter hemodinamik pada pasien syok anak pasca resusitasi cairan dan terapi obat-obatan vasoaktif. (Tesis). Program Pendidikan Dokter Spesialis-2 Ilmu Kesehatan Anak. Jakarta: Fakultas Kedokteran Universitas Indonesia; 2015.

12. Ferrari M, Jung C, Lauten A, Pfeifer R, Figulla HR. [Evaluation of microcirculatory disorders in shock patients]. Dtsch Med 
Wochenschr 2011;136:1009-13.

13. Pearson JT, Shirai M, Tsuchimochi H, Schwenke DO, Ishida T, Kangawa K, dkk. Effects of sustained length-dependent activation on in situ cross-bridge dynamics in rat hearts. Biophys J 2007;93:4319-29.

14. Sarnoff SJ, Berglund E. Ventricular function. I. Starling's law of the heart studied by means of simultaneous right and left ventricular function curves in the dog. Circulation 1954;9:706-18.

15. Michard F, Chemla D, Richard C, Wysocki M, Pinsky MR, Lecarpentier Y, dkk. Clinical use of respiratory changes in arterial pulse pressure to monitor the hemodynamic effects of PEEP. Am J Respir Crit Care Med 1999;159:935-9.

16. Marik PE, Cavallazzi R, Vasu T, Hirani A. Dynamic changes in arterial waveform derived variables and fluid responsiveness in mechanically ventilated patients: a systematic review of the literature. Crit Care Med 2009;37:2642-7.

17. Lukito V, Djer MM, Pudjiadi AH, Munasir Z. The role of passive leg raising to predict fluid responsiveness in pediatric intensive care unit patients. Pediatr Crit Care Med 2012;13:e155-60.

18. Moreno FL, Hagan AD, Holmen JR, Pryor TA, Strickland RD, Castle $\mathrm{CH}$. Evaluation of size and dynamics of the inferior vena cava as an index of right-sided cardiac function. Am J Cardiol 1984;53:579-85.

19. Kircher BJ, Himelman RB, Schiller NB. Noninvasive estimation of right atrial pressure from the inspiratory collapse of the inferior vena cava. Am J Cardiol 1990;66:493-6.

20. Nagueh SF, Kopelen HA, Zoghbi WA. Relation of mean right atrial pressure to echocardiographic and Doppler parameters of right atrial and right ventricular function. Circulation 1996;93:1160-9.

21. Airapetian N, Maizel J, Alyamani O, Mahjoub Y, Lorne E, Levrard M, dkk. Does inferior vena cava respiratory variability predict fluid responsiveness in spontaneously breathing patients? Crit Care 2015;19:400. 